\title{
Sartre on Munich 1972
}

\section{1) Summary of Events}

The first internationally staged "terrorist" event-the Palestinian kidnapping of Israeli athletes-occurred in Munich Germany during the 1972 Summer Olympics. Sartre's article "About Munich" concerns this event.

This summary of events is based on reports in the New York Times of Sept. 6, 7, and 9, 1972. At roughly 5AM local time on June 6, 1972, five Palestinians joined three others near the living quarters of the Israeli athletes and attacked. Two athletes were immediately killed; many fled; nine were held hostage (three were coaches, four were athletes, and two were Israeli security men). By 9AM the kidnappers had identified themselves as the Palestinian Black September group and negotiations began with the Munich police chief, Dr. Manfred Schreiber; the Interior Minister, Hans Dietrich Genscher; the Bavarian state Interior Minister, Bruno Merk; the President of the International Olympic Committee, Avery Brundage; the Arab League's representative in Bonn, Mohammed Khatib; the Tunisian Ambassador; and others. The Palestinians demanded the release of 200 Palestinian prisoners in Israel and safe passage out of West Germany. Golda Meir, then the Israeli Prime Minister, refused any concessions.

The negotiators and Palestinians agreed to fly the Israelis and the Palestinians by helicopter to a near-by military base where they would board a plane for Tunisia. Around 9PM, three helicopters arrived in the Olympic Village. The eight Palestinians, nine Israelis, and three German officials boarded the helicopters and flew to the nearby military base. Mr. Brundage gave the instruction that the Palestinians were not to leave the country with the Israelis. As the transfer from the helicopters to the airplane was being initiated around 10:30PM, shots were fired. Within minutes, all the Israeli athletes and five Palestinians were killed; three Palestinians were wounded and later arrested.

The New York Times of Sept. 7, 1972, quoted the Munich police chief Dr. Schreiber: "I had the feeling we gave the first shots." And 
the Bavarian state Interior Minister Bruno Merk was quoted as saying: "The firing was started by the police, naturally."

On Sept. 9, 1972, the New York Times reported that the U.S. government had announced "the formation of an intelligence committee to deter international political terrorism in cooperation with intelligence services of friendly foreign countries." The committee would be made up of senior officials of the State Dept., the CIA, the FBI, and the DIA.

Summary prepared by Elizabeth A. Bowman 


\section{2) Jean-Paul Sartre, “About Munich”}

\section{Translated by Elizabeth Bowman}

La Cause du peuple-J'accuse, No. 29, du 15 oct. 1972.

(Republished in Les Nouvelles littéraires, 11-17 nov., 1982, under the title "A New Sartre Scandal")

Those who affirm the sovereignty of the Israeli state and also believe Palestinians have a right to sovereignty for the same reason, and who take the Palestinian question as fundamental, must admit that the Israeli establishment's policy is literally crazy and deliberately aims at avoiding all possible solutions to this problem. It is therefore politically accurate to say that a state of war exists between Israel and the Palestinians. In this war the Palestinians' only weapon is terrorism. It is a terrible weapon but the oppressed poor have no other, and the French who approved $\mathrm{FLN}^{2}$ terrorism against the French must approve in turn the Palestinians' terrorist action. This abandoned, betrayed, exiled people can show its courage and the force of its hate only by organizing deadly attacks. Of course these should be viewed politically, by assessing the intended results against those actually obtained. We would also need to settle the highly ambiguous question of the real relationships among Arab governments, none of which is socialist nor has socialist tendencies, and the feddayin ${ }^{3}$, which leads us to ask whether the Palestinians' primary enemies may not be these feudal dictatorships, several of which have supported them verbally while at the same time trying to massacre them, and whether the first effort of the Palestinians, whose war necessarily dedicates them to socialism, must not be to side with the peoples of the Middle East against those Arab states which oppress them. But these problems cannot be treated in an article.

It must be said that for those who agree with the terrorist attacks to which the Israeli establishment and the Arab dictatorships have reduced the Palestinians, it seems perfectly outrageous that the French press and a segment of opinion should judge the Munich attack an intolerable outrage while one has often read dry reports without comment of strikes in Tel Aviv that cost several human lives. The principle of terrorism is that one must kill. And even if one is resigned to that, it remains, as it was for Albert $\mathrm{Memmi}^{4}$ who agreed with the Algerians' struggle, inexcusable after an explosion to see mutilated bodies or a child's severed head. But if one can admit it, then we must in fact recognize that the Munich attack succeeded 
perfectly. It took place amidst an international sporting event that attracted hundreds of journalists from all countries; for this reason it assumed world importance, and, thereby, put the Palestinian question before the whole world more tragically than at the UN where the Palestinians are not represented. The Palestinians aimed not at massacring the hostages on the spot but at taking them to an Arab country where they would have negotiated an exchange of Palestinian prisoners in Israel for the hostages. Similarly, while we disagree with the Israeli government on all other points, we can understand that, being at war with the Palestinians, Israel would reject all concessions. Regardless of how one judges such intransigence, it too was on display before international opinion.

The only guilty party was the Munich police. For we now know that the Palestinians did not explode the device that was to take them out, but instead everyone, feddayin and hostages, was killed by police bullets. ${ }^{5}$ That there had been disagreements between Munich and Bonn does not excuse the cops. Quite the contrary.

Thus the attack at the Olympics historically unveiled, for all to see, the despair of the Palestinian combatants and the horrible courage this despair gives them. While tactically it did not advance their cause, it showed and established better than any speech at the UN both that we must now, right away, solve the Palestinian problem and that this problem has become everyone's. The violent indignation shown by "noble" hearts in the press concerns neither Palestinians nor Israelis. These good apostles would have Israelis killed in Israel rather than disrupt the noble and classical order of the Olympic games, this sacred ceremony from ancient Greece. This reaction was foreseeable and will soon give way to a more realistic view. It is meanwhile no less ignoble. 